\title{
Molar Growth Yields, Respiration and Cytochrome Patterns of Beneckea natriegens when Grown at Different Medium Dissolved-oxygen Tensions
}

\author{
By J. D. LINTON AND D. E. F. HARRISON \\ Shell Research Ltd, Sittingbourne ME9 8AG, Kent \\ AND A. T. BULL \\ Biological Laboratory, University of Kent, Canterbury $\mathrm{CT}_{2}{ }_{7} \mathrm{NJ}$
}

(Received 5 December 1974; revised 8 May 1975)

\begin{abstract}
SUMMARY
The effect of medium dissolved-oxygen tension on the molar growth yield, respiration and cytochrome content of Beneckea natriegens in chemostat culture $\left(D 0.37 \mathrm{~h}^{-1}\right)$ was examined. The molar growth yield $(Y)$, the specific rate of oxygen $\left(q_{\mathrm{O}_{2}}\right)$ and glucose consumption, and the specific rate of carbon dioxide evolution were independent of the dissolved-oxygen tension above a critical value $(<2 \mathrm{mmHg})$. However, the potential respiration rate increased with reduction in the dissolvedoxygen tension at values of the dissolved-oxygen tension well above the critical value. Changes in the cytochrome content occurred at dissolved-oxygen tensions well above the critical value. An increase in cytochrome $c$ relative to cytochrome $b$ was observed as the dissolved-oxygen tension was decreased. Reduction of the dissolved-oxygen tension to less than $\mathrm{I} \mathrm{mmHg}$ caused a switch to fermentative metabolism shown by the apparent rise in $Y_{\mathrm{O}_{2}}$ and decrease in the molar growth yield from glucose. At this point the potential respiration rate $\left(q_{o_{2}}\right)$ increased to its highest value, while the cytochrome pattern reverted to that observed at dissolved-oxygen tensions above $96 \mathrm{mmHg}$. There appeared to be no correlation between cytochrome content, potential $q_{\mathrm{o}_{2}}$, in situ $q_{\mathrm{o}_{2}}$, and cyanide sensitivity of the organism at various dissolved-oxygen tensions.
\end{abstract}

\section{INTRODUCTION}

Beneckea natriegens, a facultative anaerobic, Gram-negative marine bacterium (Baumann, Baumann \& Mandel, 1971) provides an interesting system for the study of respiratory control in bacteria, as it apparently has four different, recognizable, cytochrome oxidases. Cytochromes $o, a_{1}$ and $d$, and a CO-binding $c$-type cytochrome, have been identified on the basis of CO difference spectra and action spectra (Weston \& Knowles, 1974). From inhibitor studies on cell-free extracts, a branched electron transport chain has been proposed for B. natriegens (Weston, Collins \& Knowles, 1974). Action spectra of whole organisms indicated that cytochrome $d$ functioned as a terminal oxidase although present only at very low concentration (Weston \& Knowles, 1974). The CO-binding $c$-type cytochrome was also found to have oxidase, activity but the evidence for cytochrome $o$ acting as an oxidase was inconclusive. In organisms cultured for periods longer than $16 \mathrm{~h}$ cytochrome $a_{1}$ was the major functional oxidase and cytochromes $d$ and $o$ and CO-binding $c$-type had minor oxidase functions (Weston \& Knowles, 1974). Meyer \& Jones (1973a,b) suggested that multiple oxidases found in bacteria function at different medium dissolved-oxygen tensions 
and are associated with different efficiencies of phosphorylation. To assess whether branching of the electron transport system occurred under physiological conditons, $B$. natriegens was grown at various medium dissolved-oxygen tensions in a glucose-limited chemostat culture and the effects on growth, respiration and cytochrome content were monitored. A preliminary report has already been published (Linton, Harrison \& Bull, 1974).

\section{METHODS}

Organism and medium. Beneckea natriegens strain Baumann I I , the gift of C. J. Knowles, University of Kent, was originally isolated and characterized by Payne, Eagon \& Williams (1961).

The basal medium contained, in a final volume of $925 \mathrm{ml}: \mathrm{Na}_{2} \mathrm{HPO}_{4}, \mathrm{I} \cdot 5 \mathrm{~g}$; $\mathrm{KH}_{2} \mathrm{PO}_{4}$, I. $5 \mathrm{~g} ;\left(\mathrm{NH}_{4}\right)_{2} \mathrm{SO}_{4}, 3.0 \mathrm{~g} ; \mathrm{NaCl}, 23 \mathrm{~g} ; \mathrm{KCl}, 0.745 \mathrm{~g}$; trace element mixture, I $\mathrm{ml}$. The trace element mixture was from a stock solution containing $(\mathrm{g} / \mathrm{l}): \mathrm{CaCl}_{2} \cdot 2 \mathrm{H}_{2} \mathrm{O}, 0 \cdot 66 ; \mathrm{ZnSO}_{4} \cdot 7 \mathrm{H}_{2} \mathrm{O}$, $0.18 ; \mathrm{CuSO}_{4} .5 \mathrm{H}_{2} \mathrm{O}, 0.16 ; \mathrm{MnSO}_{4} .4 \mathrm{H}_{2} \mathrm{O}, 0.15 ; \mathrm{CoCl}_{2} .6 \mathrm{H}_{2} \mathrm{O}, 0.18 ; \mathrm{H}_{3} \mathrm{BO}_{3}, 0.10 ;$ $\mathrm{Na}_{2} \mathrm{MoO}_{4} \cdot 2 \mathrm{H}_{2} \mathrm{O}, 0.30$; the $\mathrm{pH}$ was adjusted to $7 \cdot 3$ with $\mathrm{NaOH}$. Solutions of glucose $(2 \cdot 0 \mathrm{~g})$ with $\mathrm{MgSO}_{4} \cdot 7 \mathrm{H}_{2} \mathrm{O}(0 \cdot 2 \mathrm{~g})$ in a final volume of $50 \mathrm{ml}$ and of $\mathrm{I} \mathrm{ml} \mathrm{FeCl}$ (from a stock solution containing $\left.16.7 \mathrm{~g} \mathrm{FeCl}_{3} .6 \mathrm{H}_{2} \mathrm{O} / \mathrm{l}\right)$ in a final volume of $25 \mathrm{ml}$, were also prepared. The three components of the complete medium were autoclaved separately and mixed aseptically after cooling.

The glucose concentration of $2.0 \mathrm{~g} / \mathrm{l}$ in the feed medium has been previously shown to be growth limiting.

Fermenter cultures. An impeller-stirred, Biotec fermentation vessel (LKB) of working capacity $2 \cdot 3 \mathrm{l}$, was used. The culture volume was kept constant by means of a stainless-steel overflow tube $(6 \mathrm{~mm}$ diam), the bottom of which was connected to an effluent vessel by silicone rubber tubing. Effluent culture was pumped out of the vessel using a peristaltic pump (Northern Media Supply Ltd, Brough HUI5 $2 \mathrm{PE}$ ). The temperature was maintained at $31.50 \pm 0.25^{\circ} \mathrm{C}$ by controlling the circulation of hot and cold water through two separate fingers immersed in the culture. Culture $\mathrm{pH}$ was controlled at $7.23 \pm 0.02$ by adding $5 \mathrm{M}-\mathrm{NaOH}$ using a Titrator II (Radiometek A/S-Emdrupues, Copenhagen, Denmark). The medium, stirred at $600 \mathrm{rev}$./min, was aerated by passing sterile air through it at $1 \cdot 01 / \mathrm{min}$. Medium was pumped into the fermenter vessel with a diaphragm pump (F. A. Huges \& Co. Ltd, Epsom, Surrey), from a reservoir containing 301 which was stirred continuously with a magnetic stirrer to keep in suspension a slight precipitate which formed in the complete medium. The dilution rate was maintained at $0.37 \mathrm{~h}^{-1}$, which represented approximately $50 \%$ of the maximum growth rate. The specific rate of oxygen consumption $\left(q_{\mathrm{o}_{2}}\right)$ and of carbon dioxide production $\left(q_{\mathrm{CO}_{2}}\right)$ were shown to increase linearly with growth rate (Linton, unpublished) and metabolism to be unaffected between growth rates of $0 . \mathrm{I}$ and $0.8 \mathrm{~h}^{-1}$. Therefore, change in the growth rate of this organism would be expected to have no effect on the value of the critical dissolved-oxygen tension or the pattern of response of the culture to dissolved-oxygen tension.

The dissolved-oxygen tension was varied by changing the ratio of air to nitrogen in the inlet gas while keeping the total flow rate constant. The dissolved-oxygen tension was measured with a galvanic-cell oxygen probe (L.H. Engineering Co. Ltd, Stoke Poges, Buckinghamshire), connected in series with a $5 \mathrm{k} \Omega$ variable potentiometer. The probe was calibrated in growth medium in equilibrium with mixtures of air and nitrogen assayed by means of a Servomex oxygen analyser. The zero reading was obtained by bubbling nitrogen through the medium for $24 \mathrm{~h}$. Oxygen mixtures below I \% oxygen were obtained by mixing 
nitrogen with standard $\mathrm{O}_{2}-\mathrm{N}_{2}$ gas mixtures containing $\mathrm{I} 0$ and $\mathrm{I} \%$ oxygen. Oxygen in the gas, entering and leaving the vessel was continuously monitored by a twin-channel, paramagnetic oxygen analyser (Type OA 184, Servomex Controls Ltd, Crowborough, Sussex). Carbon dioxide leaving the vessel was continuously monitored by an infrared analyser (M.S.A. Instrument Division, Glasgow). Gas flow rates through the fermenter were measured on a wet-type gas meter (Alexander Wright and Co., London).

Analytical methods. Duplicate samples of culture $(10 \mathrm{ml})$ were centrifuged at $17000 \mathrm{~g}$ for $35 \mathrm{~min}$. The sediments were washed twice in a solution of $0.4 \mathrm{M}-\mathrm{NaCl}$ and finally taken up in distilled water and dried to constant weight at $98^{\circ} \mathrm{C}$. For each steady-state value duplicate Io $\mathrm{ml}$ samples were taken at intervals of at least five times the mean residence time.

Total culture carbon and supernatant carbon were determined with a Beckman Model 915 total organic carbon analyser. Carbon analyses of the whole culture and of a Millipore $(0.25 \mu \mathrm{m}$ pore size) filtrate were made and the carbon content of the bacteria obtained from the difference.

Glucose concentrations in the input medium and effluent culture were measured with the glucose oxidase system (Sigma Chemical Bulletin No. 510, 1969). Acetic acid and ethanol in Millipore filtrates of the culture were assayed by gas-liquid chromatography, using a Varian $\mathrm{I} 800$ series chromatograph and a Poropak Q column at $190^{\circ} \mathrm{C}$. Pyruvic acid and lactic acid were assayed enzymically (Sigma Chemical Bulletin No. 726-UV and No. 826 UV, respectively, 1968).

Culture extinction, measured at $625 \mathrm{~nm}$, was used as a guide to the constancy of the biomass content in steady-state cultures. The extinction was not used to compute carbon content or dry weight of the culture.

The amount of ammonium sulphate nitrogen used was measured from the total ammonia in the input and output media. The ammonia and orthophosphate concentrations in samples were measured using a Technicon Autoanalyser II (Industrial Methods Nos. 160-73E and I55-7I $W$, respectively).

Cytochrome spectra were recorded at room temperature and at low temperatures $\left(77^{\circ} \mathrm{K}\right)$, in a split beam spectrophotometer (Hitachi Perkin Elmer Model 356). The culture ( $800 \mathrm{ml}$ ) was rapidly drained from the fermenter at the end of a given steady state and centrifuged at $\mathrm{I} 7000 \mathrm{~g}$ for $35 \mathrm{~min}$ at $4{ }^{\circ} \mathrm{C}$. The pellet was resuspended in $10 \mathrm{mM}-\mathrm{MgCl}_{2}$ plus $50 \mathrm{~mm}$-tris$\mathrm{HCl}$ buffer $\mathrm{pH} \mathrm{7.5}$, then centrifuged at $17000 \mathrm{~g}$ and finally resuspended in $26 \mathrm{ml}$ tris- $\mathrm{HCl}$ buffer. Oxidized minus reduced difference spectra were obtained by adding a few crystals of $\mathrm{Na}_{2} \mathrm{~S}_{2} \mathrm{O}_{4}$ to one cuvette to obtain bacterial cytochromes in the reduced state, and oxidizing the bacterial cytochromes in the reference cuvette with a few crystals of $\mathrm{K}_{3} \mathrm{Fe}(\mathrm{CN})_{6}$ or one drop of $\mathrm{H}_{2} \mathrm{O}_{2}$. Carbon monoxide difference spectra were obtained by treating the contents of both cuvettes with $\mathrm{Na}_{2} \mathrm{~S}_{2} \mathrm{O}_{4}$ and bubbling a steady stream of $\mathrm{CO}$ through one cuvette for I min. The CO-treated cuvette was left in the dark for Io min before the spectra were recorded at room temperature and at low temperature $\left(77^{\circ} \mathrm{K}\right)$.

The potential respiration rate of the bacteria was measured by diluting culture samples in complete basal medium minus the carbon and nitrogen sources $(\mathrm{pH} 7 \cdot 2$ ), adding known quantities of glucose and following the oxygen uptake in an oxygen-electrode respirometer (Rank Bros, Bottisham, Cambridgeshire). The potential respiration rate $\left(q_{\mathrm{o}_{2}}\right)$, in $\mathrm{mmol} / \mathrm{g} / \mathrm{h}$, was calculated from the equation (Harrison \& Loveless, 197I):

$$
q_{\mathrm{o}_{2}}=r / x d,
$$

where $r$ is the rate of depletion of oxygen concentration as measured in the oxygen electrode cell $(\mathrm{mmol} / \mathrm{g} / \mathrm{h}), d$ the dilution factor, and $x$ the concentration of the organism $(\mathrm{g} / \mathrm{l})$. 


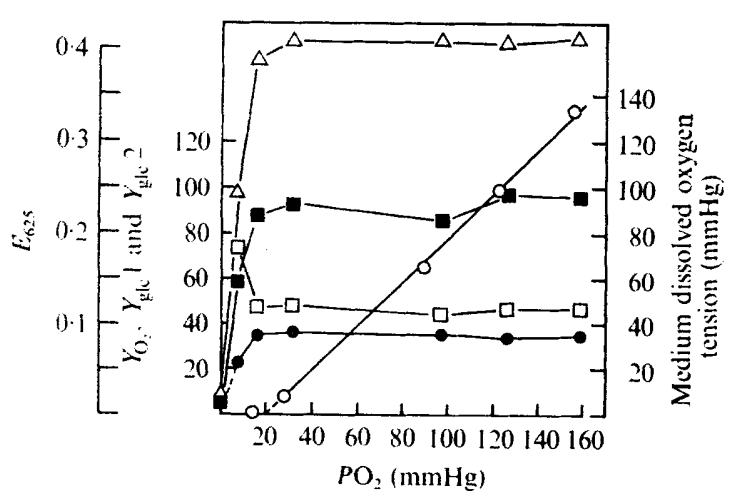

Fig. I



Fig. 2

Fig. I. Steady-state values of molar growth yields from glucose and oxygen, culture extinction and medium dissolved-oxygen tension as a function of the $\mathrm{PO}_{2}$ of a carbon-limited chemostat culture of $B$. natriegens. $\mathrm{O}$, Medium dissolved-oxygen tension $(\mathrm{mmHg}) ; \square, Y_{\text {glc }} 1$ (g bacterial dry wt $/ \mathrm{mol}$ glucose);,$Y_{\text {glc }} 2$ (g bacterial carbon/mol glucose carbon); $\square, Y_{\mathrm{O}_{2}}$ (g cell dry wt/mol oxygen); $\triangle$, culture extinction at $625 \mathrm{~nm}$.

Fig. 2. Steady-state values of glucose, nitrogen and phosphorus consumption as a function of the $\mathrm{PO}_{2}$ of a carbon-limited chemostat culture of $B$. natriegens. $\mathrm{O}, q_{\mathrm{glc}} ; \boldsymbol{O}$, nitrogen utilized; $\square$, phosphorus utilized.

\section{RESULTS}

\section{Growth physiology}

The steady-state values of molar growth yield from glucose [g bacterial dry $\mathrm{wt} / \mathrm{mol}$ ( $\left.Y_{\mathrm{glc}} \mathrm{I}\right)$, and $\mathrm{g}$ bacterial carbon/mol glucose carbon $\left.\left(Y_{\mathrm{glc}} 2\right)\right]$ appeared to be independent of medium dissolved-oxygen tension over the range $\mathrm{I} 34$ to $<2 \mathrm{mmHg}$ (partial pressure of oxygen in the gas phase $\mathrm{PO}_{2}, \mathrm{I} 59$ to $16 \mathrm{mmHg}$ ) (Fig. 1). However, reduction of the $\mathrm{PO}_{2}$ to $8 \mathrm{mmHg}$ caused a marked fall in the molar growth yield from glucose, from $92 \pm 4$ to $60 \mathrm{~g}$ bacterial dry wt $/ \mathrm{mol}$. At $\mathrm{PO}_{2}$ values below $8 \mathrm{mmHg}$ the output from the dissolved-oxygen probe was virtually zero, the dissolved-oxygen tension being below the lower limit of sensitivity of the probe ( $<\mathrm{I} \mathrm{mmHg}$ ). Further reduction of the $\mathrm{PO}_{2}$ to $<0.5 \mathrm{mmHg}$ (achieved by gassing with 'white spot' nitrogen) caused a dramatic fall in the molar growth yield. Based on culture extinction and bacterial carbon values, the yield was approximately $5 \%$ of that observed under the excess oxygen phase (Fig. I).

Reduction of the $\mathrm{PO}_{2}$ to $8 \mathrm{mmHg}$ caused no detectable effect on medium dissolved oxygen, as this was already below the lower limit of sensitivity of the probe, but the $q_{\mathrm{O}_{2}}$ of the culture decreased. The medium dissolved-oxygen tension was found to be dependent on $P_{2}$. The relationship is shown in Fig. I and is given by the equation:

$$
N=K_{\mathrm{L}} A\left(T_{\mathrm{g}}-T_{\mathrm{L}}\right),
$$

where $N$ is the oxygen uptake rate of the culture $(\mathrm{g} / \mathrm{h}), K_{\mathrm{L}} A$ the oxygen transfer coefficient $(\mathrm{g} / \mathrm{h} / \mathrm{mmHg}), T_{\mathrm{g}}$ the oxygen partial pressure in the gas phase $(\mathrm{mmHg})$, and $T_{\mathrm{L}}$ is the medium dissolved-oxygen tension $(\mathrm{mmHg})$.

The medium dissolved-oxygen tension varied linearly with partial pressure of oxygen in the effluent gas phase (Harrison, 1973).

The specific rate of glucose consumption $\left(q_{\mathrm{glc}} ; \mathrm{mmol}\right.$ glucose $/ \mathrm{g}$ bacterial dry wt/h) was calculated from the equation:

$$
q_{\mathrm{glc}}=\left(S_{\mathrm{R}}-S\right) D / \bar{x},
$$




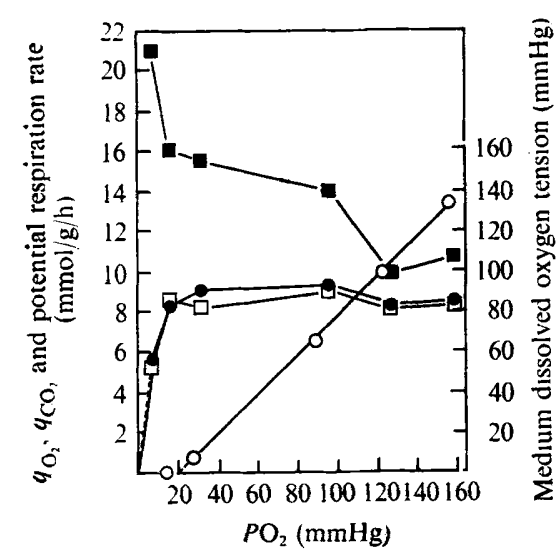

Fig. 3

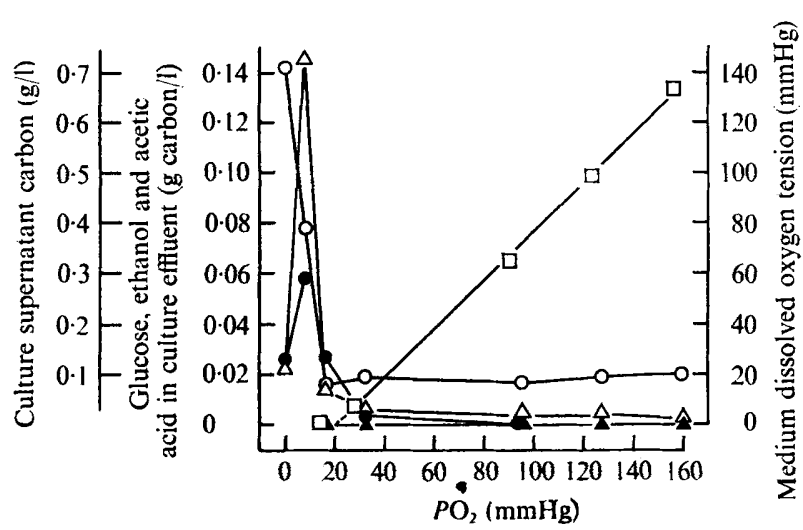

Fig. 4

Fig. 3. Steady-state values of the specific rates of oxygen consumption and $\mathrm{CO}_{2}$ production, potential respiration rate and medium dissolved-oxygen tension, as functions of the $\mathrm{PO}_{2}$ of a carbonlimited chemostat culture of $B$. natriegens. $O$, Medium dissolved-oxygen tension;,$q_{\mathrm{CO}_{2}} ; \square, q_{\mathrm{O}_{2}}$; $\square$, potential respiration rate.

Fig. 4. Steady-state values of glucose, ethanol, acetic acid, and culture supernatant carbon, and medium dissolved-oxygen tension, as functions of the $\mathrm{PO}_{3}$ of a carbon-limited chemostat culture of $B$. natriegens. $\Delta$, Glucose carbon;, , ethanol carbon; $\triangle$, acetic acid carbon; $O$, culture supernatant carbon; $\square$, medium dissolved-oxygen tension.

where $S_{\mathrm{R}}$ is the glucose concentration in the medium feed (mmol/l), $S$ the steady-state glucose concentration in the medium effluent (mmol/1), $D$ the dilution rate $\left(\mathrm{h}^{-1}\right)$, and $\bar{x}$ is the steady-state bacterial dry wt $(\mathrm{g} / \mathrm{l})$.

The $q_{\mathrm{gle}}$ was fairly constant over the range of medium dissolved-oxygen tension of 134 to $<2 \mathrm{mmHg}\left(\mathrm{PO}_{2} 156\right.$ to $\left.16 \mathrm{mmHg}\right)$ but there appeared to be about a $50 \%$ increase in the $q_{\mathrm{glc}}$ when the $P_{2}$ was reduced to $8 \mathrm{mmHg}$ (medium dissolved-oxygen tension $\ll 2 \mathrm{mmHg}$ ) (Fig. 2).

Nitrogen and phosphorus utilization by the culture was monitored and found to be independent of the dissolved-oxygen tension between 134 and $<2 \mathrm{mmHg}$ (Fig. 2). Under anaerobic conditions the bacterial mass and the amount of nitrogen and phosphorus utilized could not be measured accurately.

Both $q_{\mathrm{O}_{2}}$ and $q_{\mathrm{co}_{2}}$ were independent of medium dissolved-oxygen tension over the range 8 to $134 \mathrm{mmHg}$ (Fig. 3). When the $\mathrm{PO}_{2}$ was reduced to $16 \mathrm{mmHg}$, the medium dissolvedoxygen tension reading fell to zero (i.e. $<2 \mathrm{mmHg}$ ), but there was no effect on $q_{\mathrm{O}_{2}}$ or $q_{\mathrm{Co}_{2}}$.

The molar growth yield from oxygen $\left(Y_{\mathrm{O}_{2}}\right)$, in $\mathrm{g}$ bacterial dry wit $/ \mathrm{mol} \mathrm{O}_{2}$, was calculated from the equation (Harrison \& Loveless; 1971):

$$
Y_{\mathrm{o}_{2}}=\mu / q_{\mathrm{o}_{3}},
$$

where $\mu$ is the specific growth rate $\left(\mathrm{h}^{-1}\right)$. The values of $Y_{\mathrm{O}_{2}}$ obtained, as a function of the $\mathrm{PO}_{2}$, are shown in Fig. I. The $\mathrm{Y}_{\mathrm{O}_{2}}$ was independent of the $\mathrm{PO}_{2}$ over the range ${ }_{159}$ to $16 \mathrm{mmHg}$. However, reduction of the $P_{2}$ to $8 \mathrm{mmHg}$ caused a $37 \%$ increase in the $Y_{\mathrm{O}_{2}}$ value. The potential $q_{\mathrm{o}_{2}}$ was found to be higher than the in situ $q_{\mathrm{O}_{2}}$ at all oxygen tensions examined (Fig. 3) and increased as the partial pressure of oxygen was reduced. At dissolvedoxygen tensions between 134 and $96 \mathrm{mmHg}$, the potential $q_{\mathrm{o}_{2}}$ was approximately $10 \mathrm{mmol}$ $\mathrm{O}_{2} / \mathrm{g}$ bacterial dry $\mathrm{wt} / \mathrm{h}$. When the dissolved-oxygen tension was reduced to $65 \mathrm{mmHg}$, 
Table I. $A$ carbon balance for the growth of $B$. natriegens in chemostat culture

The values given represent averages obtained on analysis of duplicate samples taken from the chemostat at steady state at various medium dissolved-oxygen tensions.

\begin{tabular}{|c|c|c|c|c|c|c|}
\hline \multirow[b]{2}{*}{$\begin{array}{c}\mathrm{PO}_{2} \\
(\mathrm{mmHg})\end{array}$} & \multirow[b]{2}{*}{$\begin{array}{c}\text { D.o.t. } \\
(\mathrm{mmHg})\end{array}$} & \multicolumn{4}{|c|}{ Carbon output $(\mathrm{g} / \mathrm{h})$} & \multirow[b]{2}{*}{$\begin{array}{c}\text { Carbon } \\
\text { recovery }(\%)\end{array}$} \\
\hline & & $\begin{array}{c}\text { Carbon } \\
\text { input } \\
(\mathrm{g} / \mathrm{h})\end{array}$ & $\begin{array}{c}\text { Cell } \\
\text { carbon }\end{array}$ & $\begin{array}{l}\text { Product } \\
\text { carbon }\end{array}$ & $\begin{array}{l}\text { Carbon } \\
\text { dioxide } \\
\text { carbon }\end{array}$ & \\
\hline $159 \cdot 6$ & I 34 & $\begin{array}{l}0.699 \\
0.699\end{array}$ & $\begin{array}{l}0.364 \\
0.323\end{array}$ & $\begin{array}{l}0.089 \\
0.10\end{array}$ & $\begin{array}{l}0.250 \\
0.243\end{array}$ & $\begin{array}{r}100 \cdot 5 \\
94.0\end{array}$ \\
\hline 127 & 96 & $\begin{array}{l}0.690 \\
0.690\end{array}$ & $\begin{array}{l}0.34 \mathrm{I} \\
0.323\end{array}$ & $\begin{array}{l}0.082 \\
0.091\end{array}$ & $\begin{array}{l}0.237 \\
0.237\end{array}$ & $\begin{array}{l}95 \cdot 6 \\
94 \cdot 3\end{array}$ \\
\hline 95 & .65 & $\begin{array}{l}0.706 \\
0.692\end{array}$ & $\begin{array}{l}0.36 \\
0.346\end{array}$ & $\begin{array}{l}0.077 \\
0.077\end{array}$ & $\begin{array}{l}0.245 \\
0.245\end{array}$ & $\begin{array}{l}96 \cdot 5 \\
96 \cdot 5\end{array}$ \\
\hline 32 & 8 & $\begin{array}{l}0.706 \\
0.706\end{array}$ & $\begin{array}{l}0.353 \\
0.381\end{array}$ & $\begin{array}{l}0.084 \\
0.093\end{array}$ & $\begin{array}{l}0.259 \\
0.251\end{array}$ & $\begin{array}{r}98 \cdot 5 \\
102 \cdot 0\end{array}$ \\
\hline 16 & $<2 \cdot 0$ & $\begin{array}{l}0.706 \\
0.706\end{array}$ & $\begin{array}{l}0.344 \\
0.353\end{array}$ & $\begin{array}{l}0.074 \\
0.074\end{array}$ & $\begin{array}{l}0.224 \\
0.224\end{array}$ & $\begin{array}{l}91 \cdot 0 \\
92 \cdot 2\end{array}$ \\
\hline 8 & $\ll I$ & $\begin{array}{l}0.713 \\
0.718\end{array}$ & $\begin{array}{l}0.223 \\
0.251\end{array}$ & $\begin{array}{l}0.362 \\
0.353\end{array}$ & $\begin{array}{l}0.118 \\
0.118\end{array}$ & $\begin{array}{r}98 \cdot 5 \\
100 \cdot 5\end{array}$ \\
\hline 0 & 0 & $\begin{array}{l}0.798 \\
0.780\end{array}$ & $\begin{array}{l}0.06 \\
0.05 \mathrm{I}\end{array}$ & $\begin{array}{l}0.738 \\
0.729\end{array}$ & - & $\begin{array}{l}100 \\
100\end{array}$ \\
\hline
\end{tabular}

D.o.t., dissolved-oxygen tension.

the potential respiration rate increased to $14 \mathrm{mmol} / \mathrm{g} / \mathrm{h}$ with no marked increase in the in situ $q_{\mathrm{O}_{2}}$. Reduction of the dissolved-oxygen tension to $<<\mathrm{ImmHg}\left(P \mathrm{O}_{2} \mathrm{I} 6 \mathrm{mmHg}\right)$ caused a small increase in the potential $q_{\mathrm{o}_{2}}$, but further reduction of the $P \mathrm{O}_{2}$ to $8 \mathrm{mmHg}$ caused a dramatic increase in the potential respiration rate to $21 \mathrm{mmol} / \mathrm{g} / \mathrm{h}$, while the in situ $q_{\mathrm{o}_{2}}$ fell to $5 \cdot 3 \mathrm{mmol} / \mathrm{g} / \mathrm{h}$.

The formation of extracellular metabolic products from glucose, as a function of the $\mathrm{PO}_{2}$, is shown in Fig. 4. Acetic acid and ethanol were the two main products identified by g.l.c. and their concentrations remained low and fairly constant until $\mathrm{PO}_{2}$ was reduced to $16 \mathrm{mmHg}$ (medium dissolved-oxygen tension $<2 \mathrm{mmHg}$ ), when there was a slight increase in the concentration of these compounds. Both these products reached a maximum concentration when the $\mathrm{PO}_{2}$ was $8 \mathrm{mmHg}$. Pyruvic acid was found at extremely low concentrations (a maximum of $3 \mathrm{mg} / \mathrm{l}$ ) when 'white-spot' nitrogen was passed through the fermenter. The carbon balance indicated a satisfactory carbon recovery (Table I). A switch in metabolism was shown by an increase in the culture-filtrate carbon when the $\mathrm{PO}_{2}$ was reduced to $8 \mathrm{mmHg}$ (Fig. 4). Only $10 \%$ of the carbon present in culture filtrates was identified.

\section{Cytochrome analysis}

The results of oxidized minus reduced difference spectra indicated a qualitative change in the cytochrome contents of $B$. natriegens over a range of medium dissolved-oxygen tensions that caused relatively little change in the in situ $q_{\mathrm{o}_{2}}, q_{\mathrm{co}_{2}}, Y_{\mathrm{glc}}$ or $Y_{\mathrm{O}_{2}}$. At dissolved-oxygen tensions between 134 and $96 \mathrm{mmHg}$, peak extinctions at 560, 553 and $426.5 \mathrm{~nm}$ were observed, indicating the presence of $b$ - and $c$-type cytochromes (Fig. 5). The position of the Soret peak at $426 \mathrm{~nm}$ indicated a mixture of cytochromes $b$ and $c$. The ratio between cytochromes $b$ and $c$ changed as the dissolved-oxygen tension was lowered to $65 \mathrm{mmHg}$. This is 


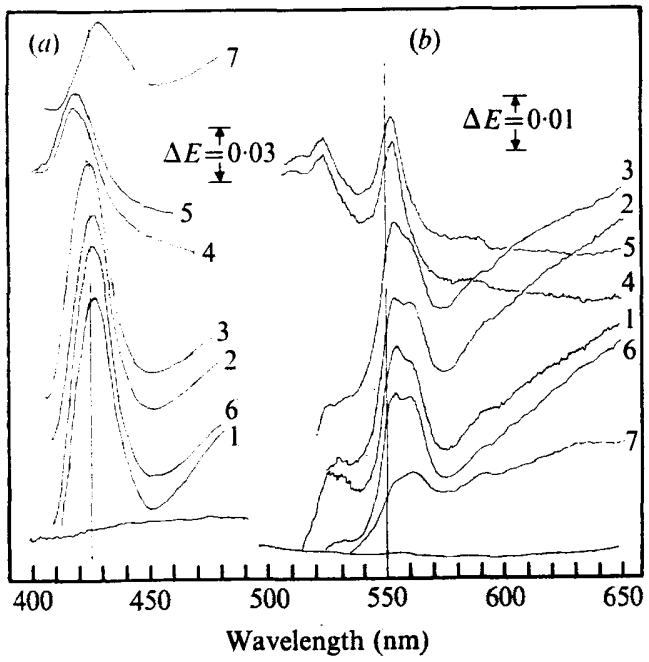

Fig. 5

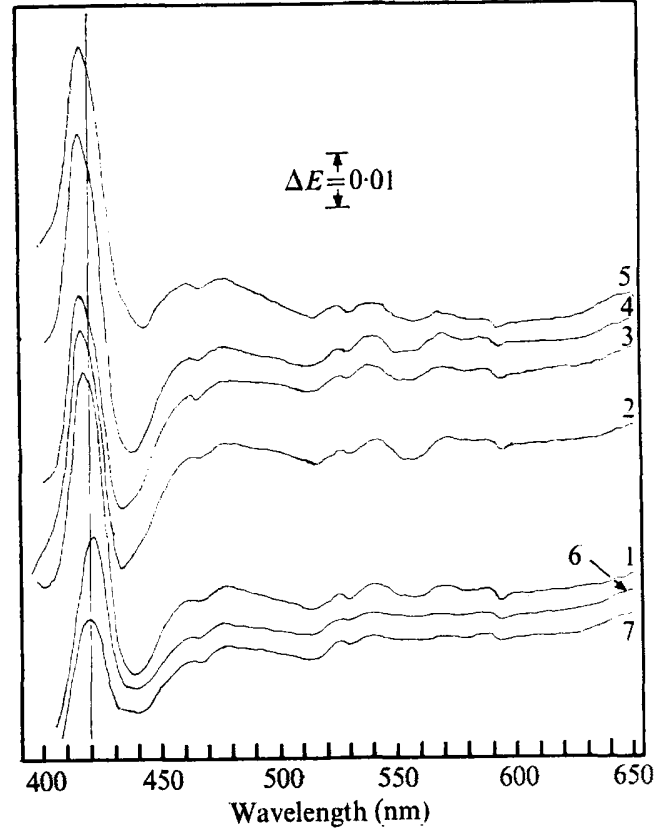

Fig. 6

Fig. 5. Room-temperature oxidized minus reduced difference spectra of whole bacteria taken from a chemostat under steady-state conditions at various medium dissolved-oxygen tensions. (a) Oxidized $\mathrm{H}_{2} \mathrm{O}_{2}$ minus reduced $\mathrm{Na}_{2} \mathrm{~S}_{2} \mathrm{O}_{4}$; (b) oxidized $\mathrm{K}_{3} \mathrm{Fe}(\mathrm{CN})_{6}$ minus reduced $\mathrm{Na}_{2} \mathrm{~S}_{2} \mathrm{O}_{4}$. (I) Medium dissolved-oxygen tension (d.o.t.) $134 \mathrm{mmHg}$, bacterial dry weight $10.26 \mathrm{mg} / \mathrm{ml}$; (2) d.o.t. $96 \mathrm{mmHg}$, bacterial dry weight $10.30 \mathrm{mg} / \mathrm{ml}$; (3) d.o.t. $65 \mathrm{mmHg}$, bacterial dry weight $10.26 \mathrm{mg} / \mathrm{ml}$; (4) d.o.t. $8 \mathrm{mmHg}$, bacterial dry weight $9.84 \mathrm{mg} / \mathrm{ml} ;(5)$ d.o.t. $<1 \mathrm{mmHg}$, bacterial dry weight $9.40 \mathrm{mg} / \mathrm{ml}$; (6) d.o.t. $\ll$ I $\mathrm{mmHg}$, bacterial dry weight $6.33 \mathrm{mg} / \mathrm{ml} ;(7)$ d.o.t. $\ll 0.5 \mathrm{mmHg}$, bacterial dry weight $2.40 \mathrm{mg} / \mathrm{ml}$.

Fig. 6. Room-temperature reduced-plus-CO minus reduced difference spectra of whole cells taken from a chemostat under steady-state conditions at various medium dissolved-oxygen tensions. (I) d.o.t. $134 \mathrm{mmHg}$; (2) d.o.t. $96 \mathrm{mmHg}$; (3) d.o.t. $65 \mathrm{mmHg}$; (4) d.o.t. $8 \mathrm{mmHg}$; (5) d.o.t. $<$ I mmHg; (6) d.o.t. $\ll$ I mmHg; (7) d.o.t. $\ll 0.5 \mathrm{mmHg}$. Bacterial dry weight as in Fig. 5 .

shown by the position of the Soret peak which appeared at $424 \mathrm{~nm}$, indicating a relative increase in the $c$-type cytochrome content. Further reduction of the dissolved-oxygen tension to 8 and $<2 \mathrm{mmHg}\left(\mathrm{PO}_{2}\right.$ values $3 \mathrm{I}$ and $\left.16 \mathrm{mmHg}\right)$ caused a further shift towards the $c$-type cytochrome. This is clearly seen in the oxidized minus reduced spectra (Fig. 5) as a shift in the Soret peak to $4 \mathrm{I} 8 \mathrm{~nm}$. Further reduction of $\mathrm{PO}_{2}$ to $8 \mathrm{mmHg}$, although causing no detectable change in the output of the dissolved oxygen probe, caused a change in which the cytochrome content appeared to revert to the pattern found in the excessoxygen phase (peak extinctions at 560, 553 and 427 ). Oxidized minus reduced difference spectra of bacteria grown in an atmosphere of nitrogen revealed small peak extinctions at 560,553 and $428 \mathrm{~nm}$.

Reduced-plus-CO minus reduced difference spectra (Fig. 6) supported the qualitative changes in the cytochrome content observed in the oxidized minus reduced difference spectra. Peak extinctions in the Soret region were at 418 and $417 \mathrm{~nm}$, at dissolved-oxygen tensions of 134 and $96 \mathrm{mmHg}$ respectively, indicating the presence of mainly cytochrome 0 . Reduction of the dissolved-oxygen tension to 65,8 and $<2 \mathrm{mmHg}$ caused a shift in the 


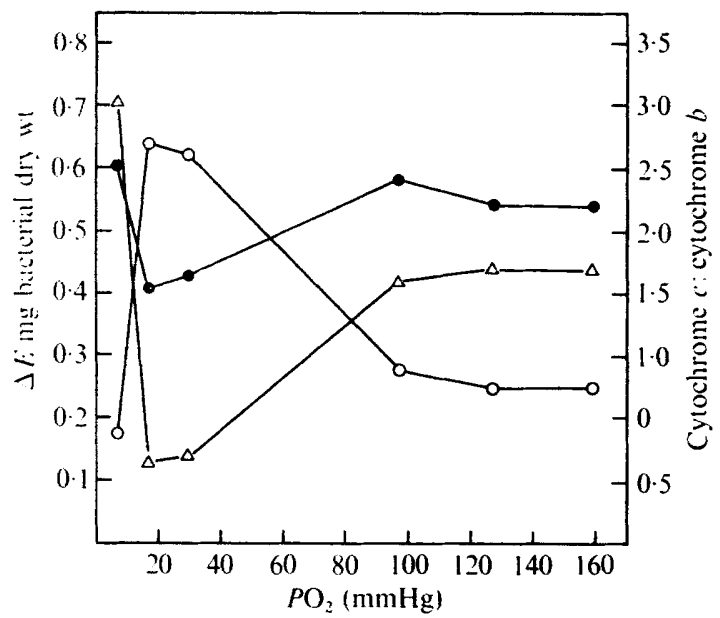

Fig. 7

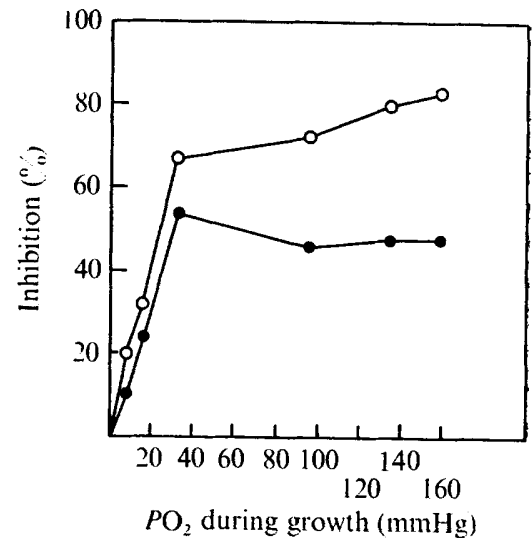

Fig. 8

Fig. 7. Steady-state values of cytochromes $c$ and $b$ and the ratio of cytochrome $c$ to cytochrome $b$ in bacteria grown at various gaseous oxygen partial pressures. Cytochrome $c$ (as $\Delta E / \mathrm{mg}$ dry wt); $\Delta$, cytochrome $b$ (as $\Delta E / \mathrm{mg}$ dry $\mathrm{wt}$ ); $\bigcirc$, ratio cytochrome $c$ : cytochrome $b$.

Fig. 8. The effect of $\mathrm{KCN}$ (as inhibition compared with a control without $\mathrm{KCN}$ ) on the potential $q_{\mathrm{O}_{2}}$ of bacteria taken from a chemostat under steady-state conditions at various gaseous-oxygen partial pressures. $\mathrm{KCN}$ was at (O) $5 \mu \mathrm{mol}$ or (O) $75 \mu \mathrm{mol}$.:

Soret peak to $4 \mathrm{I} 6 \mathrm{~nm}$, indicating a relative increase in the CO-binding cytochrome $c$. Further reduction in the $\mathrm{PO}_{2}$ to $8 \mathrm{mmHg}$, although causing no detectable change from zero on the dissolved-oxygen probe output, appeared to cause a change in the CO-liganded peak extinction from $4 \mathrm{I} 6$ to $422 \mathrm{~nm}$. Reduced-plus-CO minus reduced difference spectra of anaerobically-grown bacteria revealed a peak at $420 \mathrm{~nm}$.

Oxidized minus reduced difference spectra of whole bacteria were examined at low temperature $\left(77^{\circ} \mathrm{K}\right)$ and the results supported those obtained at room temperature. Cytochrome $b$ was detected at dissolved-oxygen tensions of 8 and $<2 \mathrm{mmHg}$ as a shoulder at $555 \mathrm{~nm}$ on a peak at $55 \mathrm{I} \mathrm{nm}$; this cytochrome $b$ was not evident in room-temperature spectra.

To obtain an estimate of the relative change in the levels of particular cytochromes, the peak heights of room-temperature oxidized minus reduced difference spectra were measured and expressed in terms of $\Delta E / \mathrm{mg}$ bacterial dry wt (Fig. 7). The changes in the levels of cytochromes $b$ and $c$ showed some relationship to the three phases observed in the potential respiration rate (see Fig. 3). The level of cytochrome $c$ appeared to remain constant over the medium dissolved-oxygen tension range 134 to $65 \mathrm{mmHg}$, whereas a reduction in the dissolved-oxygen tension from 65 to $<2 \mathrm{mmHg}$ appeared to cause a slight decline in the level of cytochrome $c$. At the $\mathrm{PO}_{2}$ that caused a switch in metabolism, the 'critical point', the level of cytochrome $c$ increased, indicating an apparent reversal to the original level. Similarly the level of cytochrome $b$ appeared to remain fairly constant over the range of dissolved-oxygen tension 134 to $65 \mathrm{mmHg}$, and declined sharply when the range was reduced to 8 and $<2 \mathrm{mHg}$. Finally, below the 'critical point' the level of cytochrome $b$ increased dramatically to a value higher than that observed under full aeration. The ratio cytochrome $c$ :cytochrome $b$ (Fig. 7) remained constant over the medium dissolved-oxygen range 134 to $65 \mathrm{mmHg}$. Reduction in the dissolved-oxygen tension to 8 and $<2 \mathrm{mmHg}$ appeared to cause an increase in the relative amount of cytochrome $c$ until the 'critical 
point' was reached, when it reverted to a ratio near that found in bacteria grown under fully aerobic conditions.

\section{Cyanide sensitivity}

The effect of 50 and $75 \mu \mathrm{mol} \mathrm{KCN}$ on the potential respiration rates of bacteria taken from the fermenter at various dissolved-oxygen tensions is shown in Fig. 8. The cyanide sensitivity of the bacteria was almost independent of the dissolved-oxygen tension over the range 134 to $8 \mathrm{mmHg}$, but below a dissolved-oxygen tension of $8 \mathrm{mmHg}$ the bacteria exhibited a marked resistance towards cyanide.

\section{DISCUSSION}

The metabolic rate and efficiency of $B$. natriegens, as indicated by the $q_{0_{2}}, q_{\mathrm{co}_{\mathrm{z}}}$ and $q_{\mathrm{glc}}$ when growing in continuous culture, was little affected by changes in dissolved-oxygen tension over a range from below the sensitivity of the oxygen probe used $(<2 \mathrm{mmHg}$ ) to $134 \mathrm{mmHg}$. In contrast, the potential $q_{\mathrm{O}_{2}}$ of the culture increased by $50 \%$ as the dissolvedoxygen tension was decreased from 100 to $65 \mathrm{mmHg}$. There was a barely significant rise in the in situ $q_{\mathrm{O}_{2}}$ over this range of dissolved oxygen, although an increase in the cytochrome $c$ content relative to cytochrome $b$ was evident. The insensitivity of metabolism to changes in the dissolved-oxygen content above a certain 'critical' level is the usual response of aerobic and facultative bacteria (Harrison, 1973). However, the changes in cytochrome content and potential respiration rate at dissolved-oxygen tensions within this range, when the metabolism of the bacteria growing in situ in the fermenter was unaffected, was an entirely unexpected result. The mechanisms for induction of the cytochrome and potential respiration rate appear to be unrelated to the actual respiration rate of the organism. Also, the actual respiration rate under carbon-limited growth is not a function of the respiratory potential of the culture or of the cytochrome content.

Even after the dissolved-oxygen tension had fallen to a level below that which could be detected by the probe, the oxygen supply could be reduced further. Reducing the oxygen supply under these conditions had a profound effect on the metabolism of the culture, as has been reported for Klebsiella aerogenes (Harrison \& Pirt, 1967). As the $\mathrm{PO}_{2}$ was reduced, with dissolved-oxygen tension less than $\mathrm{I} \mathrm{mmHg}$, there was a switch to fermentative metabolism. This was shown in an apparent rise in the $Y_{\mathrm{O}_{2}}$, a marked increase in $q_{\mathrm{glc}}$ and a decreased yield coefficient from glucose. The potential $q_{o_{2}}$ under these conditions increased dramatically to its highest value, while the cytochrome pattern reverted to that obtained at dissolved-oxygen tensions above $96 \mathrm{mmHg}$. Thus, not only was there no quantitative correlation between cytochrome content, potential $q_{\mathrm{o}_{2}}$ and in situ $q_{\mathrm{o}_{2}}$, but also, apparently, no qualitative correlation: the values changed independently of each other.

The phenomenon of increased respiration rate in the fermenter (in situ rate) in response to low dissolved-oxygen tension, as found with Escherichia coli and $K$. aerogenes (Harrison \& Pirt, 1967; Harrison \& Loveless, 1971), and which is accompanied by a switch to a less efficient pathway of glucose oxidation, was not found with $B$. natriegens.

The different branches of the electron-transport chain reported for cell-free preparations of $B$. natriegens (Weston \& Knowles, 1974) and Azotobacter (Ackrell \& Jones, 1971 $a$ ) are distinguished by a difference in cyanide sensitivity of the respective terminal oxidase of at least an order of magnitude. Therefore, if there is a change in the relative importance of these branches in response to changing dissolved-oxygen tension, as has been proposed for Azotobacter (Ackrell \& Jones, 1971 $b$ ), this should be reflected in the cyanide sensitivity of 
the bacteria. No such change in cyanide sensitivity over the dissolved-oxygen range 8 to $140 \mathrm{mmHg}$ was observed here. As the dissolved-oxygen tension fell below the sensitivity of the probe there was a steep fall in cyanide sensitivity, although the in situ and potential $q_{\mathrm{o}_{2}}$ changed little. As the oxygen supply was reduced further, cyanide sensitivity decreased along with $q_{\mathrm{O}_{2}}$. Thus, again there is no clear correlation between cyanide sensitivity and respiratory activity or yield coefficient. Moreover, the observed changes in cytochrome content could not be correlated with the cyanide sensitivity.

These studies failed to show any physiological evidence of a switch in pathways of electrons from a 'coupled' to an 'uncoupled' branch of the electron-transport system such as has been suggested for Azotobacter (Ackrell \& Jones, 1971 $b$ ) and for E. coli and $K$. aerogenes (Harrison \& Maitra, 1969), Also we found no correlation between the induction of CObinding cytochrome $c$ and cyanide sensitivity. Whatever the significance is of the multiplicity of terminal-oxidase cytochromes in B. natriegenes, it does not appear to relate to adaptation to dissolved-oxygen changes. The induction of increased cytochrome content and potential respiration rate at dissolved-oxygen tensions well above the 'critical' value raises some questions on how these organisms detect changes in dissolved oxygen which have little effect on cell metabolism or the in situ respiration rate. The reason for changes in cytochrome and respiratory potential is obscure.

We thank Dr C. J. Knowles for the provision of a culture of $B$. natriegens and the dualbeam spectroscopy facilities, and the Science Research Council for a C.A.S.E. studentship to J. D.H.

\section{REFERENCES}

ACKRell, B. A. C. \& Jones, C. W. (197I a). The respiratory"system of Azobacter vinelandii. I. Proportion of phosphorylating respiratory membranes. European Journal of Biochemistry 20, 22-28.

ACKRELL, B. A. C. \& Jones, C. W. (197I $b$ ). The respiratory system of Azobacter vinelandii. II. Oxygen effects. European Journal of Biochemistry 20, 29-35.

Baumann, P., Baumann, L. \& Mandel, M. (1971). Taxonomy of marine bacteria: the genus Beneckea. Journal of Bacteriology 107, 268-294.

HARRISON, D. E. F. (1973). Growth, oxygen and respiration. Critical Reviews in Microbiology 2, 185-228.

HARRISON, D. E. F. \& LOVELESS, J. E. (I97I). The effect of growth conditions on respiratory activity and growth efficiency in facultative anaerobes grown in chemostat culture. Journal of General Microbiology 68, 35-43.

HaRRISON, D. E. F. \& MaITRA, P. K. (1969). Control of respiration and metabolism in growing Klebsiella aerogenes: the role of adenine nucleotides. Biochemical Journal I12, 647-656.

HARRISON, D. E. F. \& PIRT, S. J. (1967). The influence of dissolved oxygen concentration on the respiration and glucose metabolism of Klebsiella aerogenes during growth. Journal of General Microbiology 46, 193-2II.

Linton, J. D., Harrison, D. E. F. \& Bull, A. T. (1974). Effect of dissolved oxygen tension on the growth and respiration of the facultative anaerobic marine bacterium Beneckea natriegens. Proceedings of the Society for General Microbiology $\mathbf{1}, 7 \mathrm{I}$.

MEYER, D. J. \& JONES, C. W. (1973a). Reactivity with oxygen of bacterial cytochrome oxidases, $a_{1}, a_{3}$ and o. FEBS Letters 33, 10I-I05.

MEYER, D. J. \& JONES, C. W. (1973b). Oxidative phosphorylation in bacteria which contain different cytochrome oxidases. European Journal of Biochemistry 36, 144-151.

Payne, W. J., Eagon, R. G. \& Williams, A. K.'(1961). Some observations on the physiology of Pseudomonas natriegens nov. spec. Antonie van Leeuwenhoek 27, $121-128$.

Weston, J. A., Collins, P. A. \& KNowles, C. J. (1974). The respiratory system of the marine bacterium Beneckea natriegens. II. Terminal branching of respirations to oxygen and resistance to inhibition by cyanide. Biochimica et biophysica acta 368, 148-157.

Weston, J. A. \& KNOWLes, C. J. (1974). The respiratory system of the bacterium Beneckea natriegens. I. Cytochrome composition. Biochimica et biophysica acta 333, 228-236. 